\title{
Modernization of Education Programs and Formation of Digital Competences of Future Primary School Teachers
}

\author{
Valentyna D. Melash ${ }^{1}$, Valentin V. Molodychenko ${ }^{1}$, Volodymyr V. Huz ${ }^{1}$, Anastasiia B. Varenychenko ${ }^{1}$ \& Svitlana S. \\ Kirsanova ${ }^{1}$ \\ ${ }^{1}$ Department of Primary Education, Educational and Scientific Institute of Social-Pedagogical and Artistic Education, \\ Bogdan Khmelnitsky Melitopol State Pedagogical University, Melitopol, Ukraine \\ Correspondence: Valentyna D. Melash, Bogdan Khmelnitsky Melitopol State Pedagogical University, 20 Hetmanska \\ str., Melitopol, 72300, Ukraine.
}

Received: June 10, 2020

Accepted: August 3, 2020

Online Published: August 14, 2020

doi:10.5430/ijhe.v9n7p377

URL: https://doi.org/10.5430/ijhe.v9n7p377

\begin{abstract}
Modernization of education programs is carried out through the digital technologies integration into the education system, in particular, into the primary education system. This leads to the integration of courses and disciplines into curricula for the development of digital competences of future primary school teachers. The purpose of the investigation was to study the features of modernization of education programs in order to form digital competences of future primary school teachers. 48 scientific publications have been examined, studied and systematized, where the integration of disciplines for the study of digital competences into the educational process of teaching future teachers is considered; consequently, three dimensions of modernization of curricula have been investigated. The first one concerns the development of general digital competences, the second one - the competence to integrate technology into educational practice, the third one - professional digital competence. It has been revealed that general digital competences are consistent with the context of the education system. Competence to integrate technologies into teaching practice focuses on the context of integration, preparing future teachers for the opportunity to use technology in future teaching of pupils, critically assess the use and teach children, using digital devices in education process. The academic paper proposes the concept of professional digital competence as the ability of a teacher to work in the context of a school education system with a digital form of education, including the process of teaching, managing digital learning environments and professional activities of a teacher. Further research should additionally explore professional digital competence in the framework of primary teacher education.
\end{abstract}

Keywords: education programs (curricula), digital competences, competence of the future teacher, digital educational system, digital curriculum

\section{Introduction}

Despite the increasing availability and prospects for the use of technologies at primary school, teachers are facing new challenges due to the growing amount of digital content available to teachers: open educational resources (OER), social media, e-textbooks, additional digital materials and software (Davies \& West, 2014; Wiley, Bliss, \& McEwen, 2014). Teachers are able to form a set of resources to make the learning process more effective. Digital content is a resource on which the effect of studying depends and which requires the application of digital skills outside of learning strategies, the use of technology to provide the content (Wiley, Bliss, \& McEwen, 2014). In general, according to recent studies, the lack of assessment of teachers' skills in mastering digital content, teachers integrate technology into pedagogy intuitively, regardless of the effectiveness of curricula and resources in teaching (Johnson, Adams Becker, Estrada, \& Freeman, 2015; Kim, Kim, Lee, Spector, \& DeMeester, 2013; Lee \& Kim, 2014). These trends determine the need to modernize curricula that will provide teachers with digital skills and competences in the selection of the most effective digital resources, materials for teaching at primary school.

The purpose of the academic paper is to study the features of modernization of education programs in order to form digital competences of future primary school teachers.

\section{Literature Review}

Curricula of teachers' development are the basis for acquiring skills and competences of future primary school teachers. Forasmuch as the process of development and changing the mode of instruction take place at schools as a 
result of the integration of technology into the educational process of primary school, teachers' training will also change (Starkey, 2020). Assessment of digital skills is an increasingly relevant subject of the investigation of teacher's competence. Studies focus on digital competences, namely the following subjects: general digital competence, competence in the field of digital learning and a new concept of professional digital competence (Starkey, 2020).

Recent studies indicate that there are four dimensions of the competences of future primary school teachers, namely: familiarization, use, integration, reorientation (Kim, Xie \& Cheng, 2017). Different levels of competence development needs require consideration of different principles and approaches to curriculum's development. Along with this, Ge, Han and Shen (2018) offer other dimensions of competence assessment: awareness, literacy, strategy and research.

On the one hand, future primary school teachers consider themselves competent in the main aspects of digital competences, and on the other hand, studies confirm teachers' perceptions and recognition that working in the development of digital skills has helped them significantly improve their competences (Porln \& Snchez, 2016).

Teachers' digital competences ensure the development of pupils' skills (Fernàndez-Cruz \& Fernàndez-Díaz, 2016). The results of the study indicate a significant difference in optimal ICT skills and low levels of teachers' competence in the development of curricula, using technology in the educational process of primary school.

The training of primary school teachers requires the study of factors that affect the level of digital competence (Fernàndez-Cruz \& Fernàndez-Díaz, 2016). There is a significant deficit in preparation for the use of technology in the educational process in developed countries. For instance, the teacher's training profile in Spain is low-average; most future teachers do not understand the essence of digital competencies; ICT resources are not used in the educational process. In case the teachers do not possess digital competences, then they are unlikely to be integrated into the educational process of primary school. In contrast, students, receiving the profession of a future teacher of primary school, highly value their own digital skills. However, the assessment of these skills indicates the need to acquire digital skills, in particular for teaching in education environment and professional development (Porln \& Snchez, 2016).

When students complete a teacher's curriculum, they should be confident in their ability to use the competences acquired during the training, in particular digital ones (Kaufman, 2015). Future teachers' training programs should be supported by experimental studies (Darling-Hammond, 2012). The investigation on the training of future teachers will change significantly in the future, because the integration of digital technologies and the development of infrastructure in the school system will gradually take place. For instance, some studies have been focused on pedagogical approaches to training primary school teachers for the development of digital competences (Røkenes \& Krumsvik, 2014), future teachers' training programs in the field of knowledge-based economy (Cochran-Smith et al., 2015), or research models (Voogt, Fisser, Roblin, Tondeur \& van Braak, 2013).

\section{Materials and Methods}

The study is based on the methodology of Starkey (2020), which offers a study of digital competencies of future teachers based on qualitative analysis of publications.

This research uses the study and analysis of quantitative researches for 2010-2020. Publications have been selected and analyzed on the basis of a systematic approach (Figure 1). The publications have been taken from the databases A + Education, Education Source and Proquest Education. The search has been carried out by keywords. 


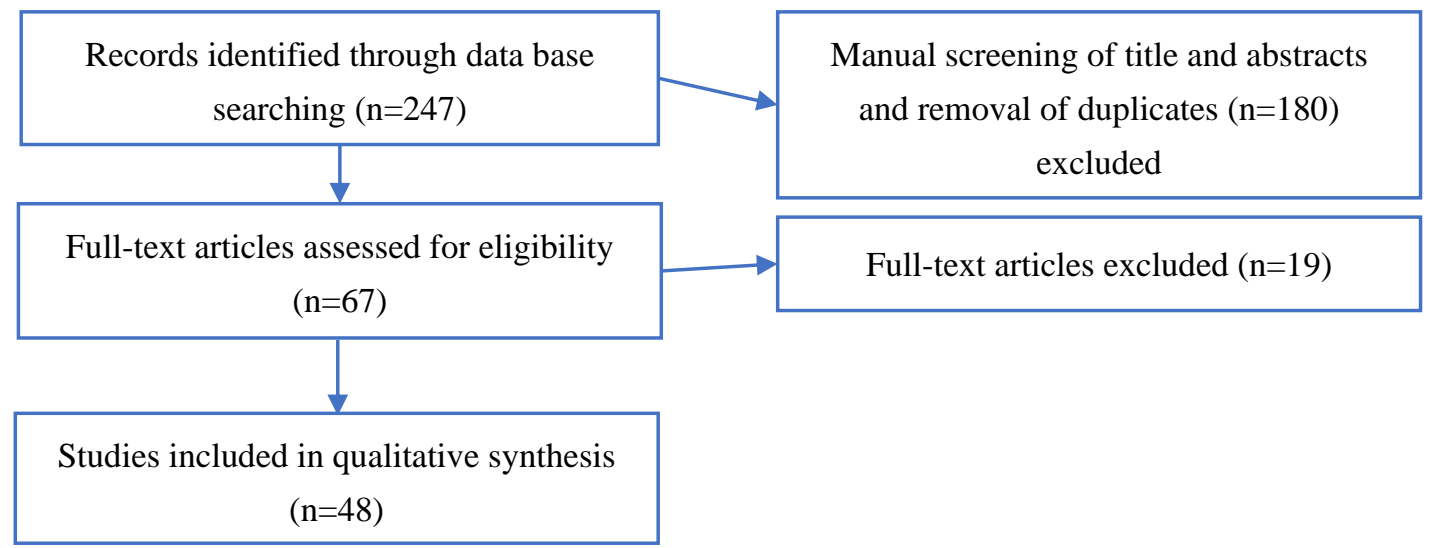

Figure 1. Article identification and selection summary

The following criteria have been used to search for and select publications for studying and analyzing the state of formation of digital competencies, namely: the research addresses the issue of curricula and standards that define teachers' digital skills; studies include a quantitative assessment of the digital competences of future primary school teachers.

The revision of the abstracts, which contained the results of research, was the first step to weed out repeated researches and investigations, which partially examine the issues of digital competences of teachers. The second phase involved manually applying exclusion criteria by reviewing titles and abstracts. Included were journal articles that reported research about preparing students for general primary or secondary school teaching in the digital age. Excluded articles examined one aspect of teacher education such as subject specific preparation, the educational use of a particular software or hardware like e-portfolios, or using digital technology to teach a particular group of students like visually impaired or EFL students. The context of education and digital technology capability is changing rapidly therefore a time limitation of 2010-2020 was applied and the initial search was limited to peer reviewed journal articles. In the end, 67 articles were selected for inclusion in the analysis. The study of the results of 67 articles led to the exclusion of 19 , which did not contain the results of the development of the theory. In the end, 48 articles were received for literature review and analysis.

Key words of search for publications in databases have been selected as follows: digital competences of teachers, curricula, modernization of educational training programs, formation of digital competences of future teachers, digital competences of primary school teachers. Due to duplicate key words, some posts reappeared in the search. Key words became the basis for the formation of major trends in the formation of digital competences of future teachers. Relevance also served as a search criterion.

\section{Results}

\subsection{Initial Teacher Education Program}

Scientific publications generally study the curricula of school teachers, namely the articles focus on the development of curricula, the effectiveness of students' studying and the interconnection between the curriculum and the learning process itself. The basic direction of research in this context was the study of the development of digital skills and competences of teachers. Accordingly, the study of curricula addressed the problems of modernization in the context of the formation of digital competences. Instefjord and Munthe (2016) have studied the positioning of digital skills in curricula. This contradicts the study that has examined the learning of students - future teachers through their initial curriculum. For instance, the features of the development of digital skills of teachers and students depending on the initial curricula (Gill \& Dalgarno, 2017; Shinas, Karchmer-Klein, Mouza, Yilmaz-Ozden \& Glutting, 2015) and "the development of student teachers' technology-enabled learning design thinking” have been studied (Bower, Highfield, Furney \& Mowbray, 2013). These studies concerned the specifics of curricula in the context of teachers' training in digital pedagogy. Curriculum development along with future teachers' training potentially ensures the effectiveness of primary school teaching methods. Studies have included such issues as: the impact of educational curricula on the development of digital competences of teachers (Røkenes \& Krumsvik, 2014; Urbani, Roshandel, Michaels \& Truesdell 2017), in what way features of the curriculum determine the intentions and abilities to use technology by teachers and students (Aslan \& Chang, 2017; Baydas \& Goktas, 2016), ways and methods of integration of digital 
technologies by educational institutions into the educational process (Tondeur, Roblin, van Braak, Fisser \& Voogt, 2013; Instefjord, 2015), the interconnection between the use of technology in the curriculum and primary programs (Tondeur, Roblin, van Braak, Voogt \& Prestridge, 2016).

Two consecutive indirect studies have examined the curricula concerning students' studying and development of curricula. One study examined the impact of development of curricula on the capacity development of future teachers. Another study examined students' perceptions of the quality of ITE programs in connection with the development of digital skills (Gudmundsdottir \& Hatlevik, 2018; Koh, Woo, \& Lim, 2013). Researches focus on teachers - students that develop general digital skills and integrate technology into learning proccess.

Investigations of the initial preparation of teachers for digital pedagogy include the study of three key aspects. The first subject of research refers to confidence, attitudes, perceptions, personal qualities, teacher's temperament, competence. Studies have found a link between these features and digital competences of teachers. The second subject of research refers to pedagogical approaches and digital competences of teachers. The third subject refers to curricula for teachers, namely the design of education, the learning process within a particular curriculum, the interconnection between a particular design and learning process. The issue of digital competences was central in these three research subjects, including the following interpretations: general digital skills, skills of integration of technologies into educational practice, a new field of research - professional digital competence.

\subsection{Digital Competence}

The interconnection between the teacher and educator assessment reflects the relationship between students and teacher assessment in research on general digital competence and teaching practice. The general digital competence of teachers and educators is considered as a prerequisite for the digital integration of technology into learning process. In particular, the issue of perception of digital integration and competence among teachers is studied (Instefjord, 2015), assessment of confidence and competence of teachers - educators regarding the integration of technology into the educational process and teaching practice (Brun \& Hinostroza, 2014), examination of curricula for the development of opportunities for integration of technologies by teachers in digital practical pedagogy and model approaches to teachers' training (Bower, Highfield, Furney, \& Mowbray, 2013). Two studies examine the integration of technology by teachers in practice (Brun \& Hinostroza, 2014) and one potential development of the teacher and mentor collaboration in the context of technology integration.

The Instefjord and Munthe study (2017) examines the ability of teachers to prepare students for the independent integration of technology into teaching practice. Digital competences have been measured on the basis of indicators: studying of students to use digital tools and ethical issues of use through the use of social networks; use of interactive whiteboard and digital tools, evaluation methods. These indicators prove the preparation of teachers for the integration of digital technologies into teaching practice.

\subsection{Student-teacher: Personal Characteristics}

The studiess analyze digital competences and at the same time the confidence, attitudes, beliefs, effectiveness of students - future teachers in terms of use of technology. Six studies presented the results of this issue: the level of confidence of students and teachers in terms of use of technology to develop curricula (Jamieson-Proctor, Finger \& Albion, 2010), effectiveness or confidence of students, future teachers (Yeung, Lim, Tay, Lam-Chiang \& Hui, 2012) or intentions to use technology in learning process (Baydas \& Goktas, 2016; Baydas \& Yilmaz, 2018), the impact of beliefs, trust and attitudes on learning technology (Aslan \& Chang, 2017; Chen, 2010; Tondeur, Scherer, Siddiq, Baran, 2017), the impact of students' self-efficacy in niche areas on the level of technology use (Elstad \& Christophersen, 2017), beliefs and attitudes towards the use of technology in inclusive education and practice (Beacham \& McIntosh, 2014) digital competences (Gudmundsdottir \& Hatlevik, 2018). These subjects matters identify different elements of learning proccess in the digital education system. Over time, the active integration of digital technologies into the educational process will lead to the usual practice of their use, and accordingly the beliefs about the use will be positive, the level of trust will increase. The effectiveness of technology will become less and less attractive subject of research in the general system of studying the motivation and efficiency of staff.

\section{Discussion}

In the literature digital competences have been the dominant subject of study. Herewith, three key interpretations and understanding of the essence of this term have been defined: general digital competence, ability to integrate skills into practice, professional digital competence. At the same time, the interpretation of the term depends on such features as the stages of digital integration, integration at school, integration into the existing system and the practice of use in the educational process. 
General investigations reflect the idea of the integration of digital competences. Experience of use still remains limited, teachers' curricula are aimed at developing computer skills (Maderick, Zhang, Hartley \& Marchand, 2016). In general, the formation of digital competences occurs through the use of general software and presentations to visualize the material. Competences' development can occur if technologies are integrated into the educational environment as a whole. An additional factor of development is gaining experience. If teachers do not have the skills to use technology, the curriculum indicates the level and list of general competences (Shinas, Karchmer-Klein, Mouza, Yilmaz-Ozden \& Glutting 2015).

The ability to integrate technology in the practical activities of the teacher indicates the second phase of integration and a higher level of digital competence. This level includes three stages: the ability to learn, the use of technology, critical evaluation of decisions in the learning process of students. At this level, there are problems with the availability of technology available to teachers. Educational institutions provide training for teachers in order to integrate technology into practice. This implies the availability of a number of training programs depending on the educational process and training system, access to the Internet (Figure 2).
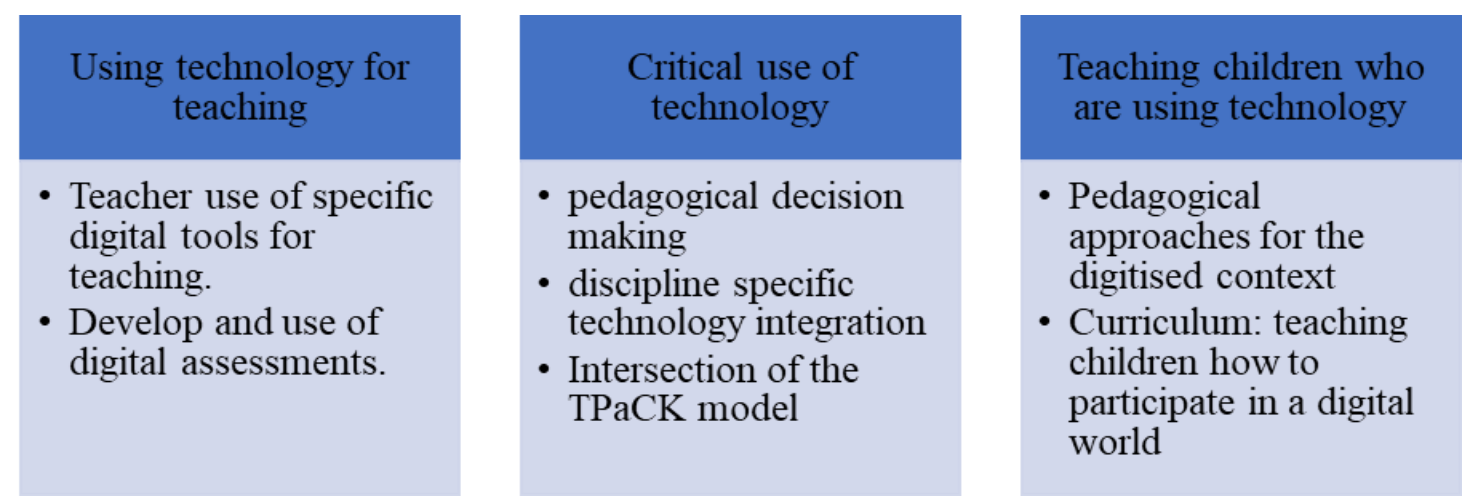

Figure 2. Dimensions of technology integration into teaching practices (Starkey, 2020)

Research on the use of technology in the teaching of future teachers has focused on whether students - teachers use specific digital tools in their teaching practice, as well as the development and integration of digital assessment tools. Assessing whether students - teachers use technology in their training provides a context where technology is integrated but not embedded in the learning process; if this is common practice of teachers and assessment by using digital technologies, such research measurements would be superfluous, as well as measuring whether students teachers used the board 20 years ago. However, studies that evaluate the use of digital and assessment tools and identify effective ways for students - teachers to master their use can be a source for decision-making in developing future teachers' curricula.

The research on the critical use of technology for teaching is supported by the concept of teacher agency through pedagogical decisions in primary teacher education (Loughran, Keast \& Cooper, 2016). This is consistent with the studies examining teachers' decisions at the intersection of technological, pedagogical, and substantive knowledge in the TPaCK model (Voogt, Fisser, Roblin, Tondeur \& van Braak, 2013). Figure 3 represents the main elements of the digital competence. 


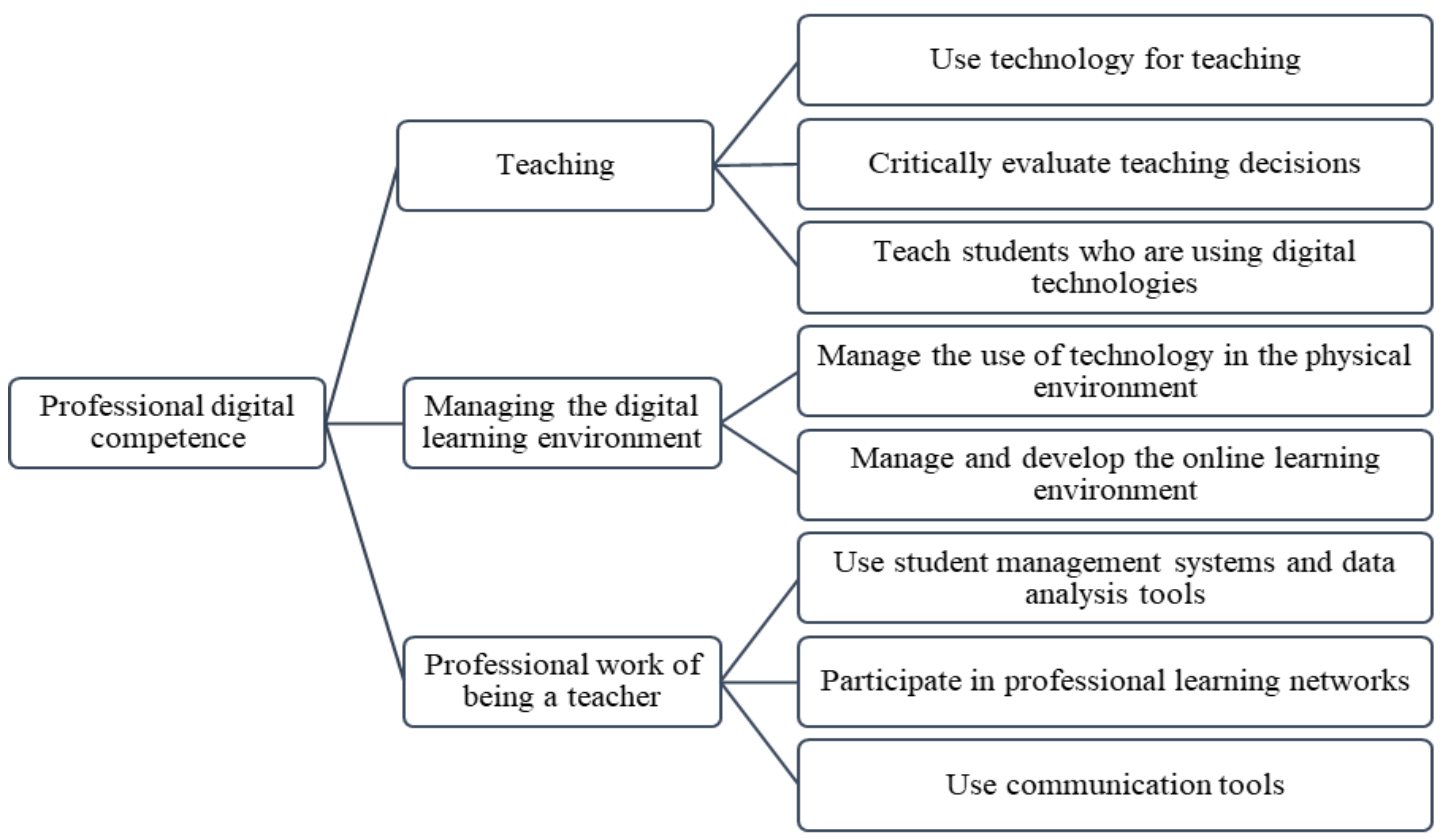

Figure 3. Professional digital competence (Starkey, 2020)

The studies have also focused on the issue how teachers learn to manage the digital learning environment, while scientists explore how to integrate technology into teaching practice. Teachers use learning management systems and curricula to organize students' learning. This includes aspects that reflect physical space, such as managing students' interaction, online resources, motivating and assessment of students. Management of the digital learning environment has two aspects: "managing the devices using in the physical learning environment, which was included in six studies" (Kabakci Yurdakul \& Çoklar, 2014; Elstad \& Christophersen, 2017; Tondeur, Scherer, Siddiq \& Baran, 2017); the second is about managing the "online learning environment", that is main focus in our study. In the online learning environment, there are functions that are not present in the physical learning environment, for example, the use of distance control systems that provide access to teachers and students to materials (Starkey \& Eppel, 2019). The development of digital resources and their management in this study is little studied, but the skills of formation of digital resources in the literature have been considered (Kumar \& Vigil, 2011). There are also unexplored areas of pedagogical science in the context of our investigation - the study of teachers regarding the skills of students in digital environment management.

One of the elements of digital competence is the ability and opportunity for teachers' participation in the digital education system. The basis of vocational training is the connection between networks and access to research, data, on which the concept of professional practice of teachers is based. In particular, it can be conducted in the form of participation in online societies, forums, informal teachers' training. Thus, teachers can improve the knowledge base (Tondeur, Scherer, Siddiq \& Baran, 2017). Further investigations should address the areas of development of professional digital competence of teachers.

Three types of digital competencies constitute the basis for the study of educational pedagogical education in terms of development of the digital educational environment (Table 1). There are differences and similarities between competences. For example, general skills include the ability to integrate technology into the learning process and learning practices. Professional competences include skills of integration into practice. 
Table 1. Digital competences in context (Developed by the author)

\begin{tabular}{|c|c|c|c|}
\hline & Generic digital competences & $\begin{array}{l}\text { Digital teaching } \\
\text { competences }\end{array}$ & $\begin{array}{l}\text { Professional digital } \\
\text { competences }\end{array}$ \\
\hline $\begin{array}{l}\text { Competences } \\
\text { examined. Ability } \\
\text { to: }\end{array}$ & $\begin{array}{l}\text { Use presentation, creative, } \\
\text { collaborative and } \\
\text { communication software and } \\
\text { Use hardware such as } \\
\text { datashows, cameras and } \\
\text { printers }\end{array}$ & $\begin{array}{lr}\text { Teach using } & \text { digital } \\
\text { technologies } & \text { Evaluate } \\
\text { teaching } & \text { decisions } \\
\text { critically Teach } & \text { students } \\
\text { who are using } & \text { digital } \\
\text { technology } & \end{array}$ & $\begin{array}{l}\text { Teach using digital } \\
\text { technologies Manage digital } \\
\text { learning environments Use } \\
\text { systems and tools in the } \\
\text { professional work as a } \\
\text { teacher. }\end{array}$ \\
\hline $\begin{array}{l}\text { ITE program aim. } \\
\text { Teachers to } \\
\text { develop: }\end{array}$ & $\begin{array}{l}\text { Technical knowledge to use } \\
\text { technologies for teaching. }\end{array}$ & $\begin{array}{l}\text { Knowledge of how to apply } \\
\text { digital technologies to } \\
\text { replace or enhance } \\
\text { established } \quad \text { teaching } \\
\text { practices. }\end{array}$ & $\begin{array}{l}\text { Knowledge of how to be a } \\
\text { teacher in a digitally infused } \\
\text { schooling system }\end{array}$ \\
\hline $\begin{array}{l}\text { Educational } \\
\text { context. }\end{array}$ & $\begin{array}{l}\text { Introduction of digital } \\
\text { technologies. }\end{array}$ & $\begin{array}{l}\text { Integration of digital } \\
\text { technologies into teaching } \\
\text { programs }\end{array}$ & $\begin{array}{l}\text { Infusion of digital } \\
\text { technologies across the } \\
\text { work of a teacher. }\end{array}$ \\
\hline ITE program & $\begin{array}{l}\text { Course on how to use digital } \\
\text { technologies }\end{array}$ & $\begin{array}{l}\text { Course on how to teach } \\
\text { with digital technologies }\end{array}$ & $\begin{array}{l}\text { Digital technology use } \\
\text { infused across the program }\end{array}$ \\
\hline
\end{tabular}

The research, where it is studied, and how the training should take place as part of the initial teacher training programs, seems to be consistent with the type of digital competences that are given priority. Prospects depended on stand-alone courses not related to school practice for teaching general digital competences, in addition to the fact that curricula should contain digital competences used in the courses. A separate course on general digital competences has been proposed (Shinas, Karchmer-Klein, Mouza, Yilmaz-Ozden, \& Glutting, 2015) in order to explore specific aspects of $\mathrm{TPaCK}$ or technological knowledge. If it is important to integrate technology into practice in the educational process, then the curriculum should include an integration plan. In contrast to this study, others provide the exclusive nature of pedagogical learning tools (Baydas \& Goktas, 2016) or they should be integrated into all subjects within the educational program (Instefjord \& Munthe, 2017). If it is necessary to achieve the development of professional competences of a teacher, the competences of a teacher should be integrated into the curriculum. The further studies should address how to prepare teacher - student for school conditions through the development of competences (Voogt, Knezek, Christensen \& Lai, 2018).

\section{Conclusion}

Primary teacher education is the process of preparing teachers for the learning context in which they will be involved. Primary education programs for teachers are changing due to changing context of learning through the introduction of digital technologies, their integration and application in the education system. Studies are developing on primary education of teachers in the context of the formation of digital competences, through the integration of digital tools in the educational process, their use in the school system and education. Investigation of digital competence focuses on such key subjects: general digital competence, competence to integrate technology into educational practice and professional digital competence. General digital competences are consistent with the context of the educational system, so the issue of studying the features of the training of future primary school teachers is relevant. The competence to integrate technology into educational practice focuses on the integration context, preparing future teachers for the opportunity to use technology in future students' training, to critically assess the use and educate children who use digital devices in learning. The third type of competence is being formed in the literature. In this academic paper, the concept of professional digital competence was developed and defined as the ability of a teacher to work in the context of a digital education system, including the learning process, to manage the digital learning environment and the professional work of teachers. Further research should additionally explore professional digital competence in the framework of primary teacher education. 


\section{References}

Aslan, A., \& Chang, Z. (2017). Investigating variables predicting Turkish pre-service teachers' integration of ICT into teaching practices. British Journal of Educational Technology, 48(2), 552-570. https://doi.org/10.1111/bjet.12437.

Baydas, O., \& Goktas, Y. (2016). Influential factors on preservice teachers' intentions to use ICT in future lessons. Computers in Human Behavior, 56, 170-178. https://doi.org/10.1016/j.chb.2015.11.030

Baydas, O., \& Yilmaz, R. M. (2018). Pre-service teachers' intention to adopt mobile learning: A motivational model. British Journal of Educational Technology, 49(1), 137-152. https://doi.org/10.1111/bjet.12521

Beacham, N., \& McIntosh, K. (2014). Student teachers' attitudes and beliefs towards using ICT within inclusive education and practice. Journal of Research in Special Educational Needs, 14(3), 180-191. https://doi.org/10.1111/1471-3802.12000

Bower, M., Highfield, K., Furney, P. \& Mowbray, L. (2013). Supporting pre-service teachers' technology-enabled learning design thinking through whole of programme transformation. Educational Media International, 50(1), 39-50. https://doi.org/10.1080/09523987.2013.777183

Brun, M., \& Hinostroza, J. E. (2014). Learning to become a teacher in the 21st century: ICT integration in initial teacher education in Chile. Journal of Educational Technology \& Society, 17(3), 222-238.

Chen, R. J. (2010). Investigating models for preservice teachers' use of technology to support student-centered learning. Computers \& Education, 55(1), 32-42. https://doi.org/10.1016/j.compedu.2009.11.015

Cochran-Smith, M., Villegas, A. M., Abrams, L., Chavez-Moreno, L., Mills, T. \& Stern, R. (2015). Critiquing teacher preparation research: An overview of the field, part II. Journal of Teacher Education, 66(2), 109-121. https://doi.org/10.1177/0022487114558268

Darling-Hammond, L. (2012). Powerful teacher education: Lessons from exemplary programs. New York, NY: John Wiley \& Sons.

Davies, R. S., \& West, R. E. (2014). Technology integration in schools. In J. M. Spector, M. D. Merrill, J. Elen, \& M. J. Bishop (Eds.), Handbook of research on educational communications and technology (pp. 841-853). New York, NY: Springer. https://doi.org/10.1007/978-1-4614-3185-5_68

Elstad, E., \& Christophersen, K.-A. (2017). Perceptions of digital competency among student teachers: Contributing to the development of student teachers' instructional self-efficacy in technology-rich classrooms. Education Sciences, 7(1), 1-15. https://doi.org/10.3390/educsci7010027

Fernàndez-Cruz, J. F., \& Fernàndez-Díaz, M. J. (2016). Generation z's teachers and their digital skills. Comunicar. Media Education Research Journal, 24(1), 97-105. https://doi.org/10.3916/C46-2016-10

Ge, W., Han, X., \& Shen, X. (2018). Developing a Validated Instrument to Measure Teachers' ICT Competencies for University Teaching in a Digital Age. In W. Zhang, Y. Wang \& M. Li (Eds.), 2018 Seventh International Conference of Educational Innovation through Technology (EITT), (pp. 101-105). Piscataway, NJ: Institute of Electrical and Electronics Engineers. https://doi.org/10.1109/EITT.2018.00028

Gill, L. \& Dalgarno, B. (2017). A qualitative analysis of pre-service primary school teachers' TPACK development over the four years of their teacher preparation programme. Technology, Pedagogy and Education, 26(4), 439-456. https://doi.org/10.1080/1475939X.2017.1287124

Gudmundsdottir, G. B. \& Hatlevik, O. E. (2018). Newly qualified teachers' professional digital competence: Implications for teacher education. European Journal of Teacher Education, 41(2), 214-231. https://doi.org/10.1080/02619768.2017.1416085

Instefjord, E. (2015). Appropriation of digital competence in teacher education. Nordic Journal of Digital Literacy, $10,155-171$.

Instefjord, E., \& Munthe, E. (2016). Preparing pre-service teachers to integrate technology: An analysis of the emphasis on digital competence in teacher education curricula. European Journal of Teacher Education, 39(1), 77-93. https://doi.org/10.1080/02619768.2015.1100602

Instefjord, E., \& Munthe, E. (2017). Educating digitally competent teachers: A study of integration of professional digital competence in teacher education. Teaching and Teacher Education, 67, 37-45. https://doi.org/10.1016/j.tate.2017.05.016 
Jamieson-Proctor, R., Finger, G., \& Albion, P. (2010). Auditing the TK and TPACK confidence of pre-service teachers: Are they ready for the profession? Australian Educational Computing, 25(1), 8-17.

Johnson, L., Adams Becker, S., Estrada, V. \& Freeman, A. (2015). NMC horizon report: 2015 K-12 edition. Austin, TX: The New Media Consortium.

Kabakci Yurdakul, I., \& Çoklar, A. N. (2014). Modeling preservice teachers' TPACK competencies based on ICT usage. Journal of Computer Assisted Learning, 30(4), 363-376. https://doi.org/10.1111/jcal.12049.

Kaufman, K. (2015). Information communication technology: Challenges \& some prospects from preservice education to the classroom. Mid-Atlantic Education Review 2(1), 1-11.

Kim, C., Kim, M., Lee, C., Spector, J. M., \& DeMeester, K. (2013). Teacher beliefs and technology integration. Teaching and Teacher Education, 29, 76-85. https://doi.org/10.1016/j.tate.2012.08.005

Kim, M. K., Xie, K., \& Cheng, S. L. (2017). Building teacher competency for digital content evaluation. Teaching and Teacher Education, 66, 309-324. https://doi.org/10.1016/j.tate.2017.05.006

Koh, J., Woo, H.-L., \& Lim, W.-Y. (2013). Understanding the relationship between Singapore preservice teachers' ICT course experiences and technological pedagogical content knowledge (TPACK) through ICT course evaluation. Educational Assessment, Evaluation and Accountability, 25(4), 321-339. https://doi.org/10.1007/s11092-013-9165-y

Kumar, S., \& Vigil, K. (2011). The net generation as preservice teachers: Transferring familiarity with new technologies to educational environments. Journal of Digital Learning in Teacher Education, 27(4), 144-153. https://doi.org/10.1080/21532974.2011.10784671

Lee, C.-J., \& Kim, C. (2014). An implementation study of a TPACK-based instructional design model in a technology integration course. Educational Technology Research and Development, 62(4), 437-460. https://doi.org/10.1007/s11423-014- 9335-8

Loughran, J., Keast, S., \& Cooper, R. (2016). Pedagogical reasoning in teacher education. In J. Loughran \& M. Hamilton (Eds.), International handbook of teacher education (pp. 387-421). Singapore: Springer. https://doi.org/10.1007/978-981-10-0366-0_10

Maderick, J., Zhang, S., Hartley, K., \& Marchand, G. (2016). Preservice teachers and self-assessing digital competence. Journal of Educational Computing Research, 54(3), 326-351. https://doi.org/10.1177/0735633115620432

Porln, I. G. \& Snchez, J. S. (2016). Evaluation and development of digital competence in future primary school teachers at the University of Murcia. Journal of New Approaches in Educational Research (NAER Journal), 5(1), 51-56. https://doi.org/10.7821/naer.2016.1.152

Røkenes, F. M. \& Krumsvik, R. J. (2014). Development of student teachers' digital competence in teacher education. A literature review. Nordic Journal of Digital Literacy, 9(4), 250-280.

Shinas, V. H., Karchmer-Klein, R., Mouza, C., Yilmaz-Ozden, S., \& Glutting, J. (2015). Analyzing preservice teachers' technological pedagogical content knowledge development in the context of a multidimensional teacher preparation program. Journal of Digital Learning in Teacher Education, 31(2), 47-55. https://doi.org/10.1080/21532974.2015.1011291

Starkey, L. (2020). A review of research exploring teacher preparation for the digital age. Cambridge Journal of Education, 50(1), 37-56. https://doi.org/10.1080/0305764X.2019.1625867

Starkey, L. \& Eppel, E. (2019). Digital data in New Zealand schools: Policy reform and school leadership. Educational Management Administration \& Leadership, 47(4), 640-658. https://doi.org/10.1177/1741143217745881

Tondeur, J., Roblin, N. P., van Braak, J., Fisser, P., \& Voogt, J. (2013). Technological pedagogical content knowledge in teacher education: In search of a new curriculum. Educational Studies, 39(2), 239-243. https://doi.org/10.1080/03055698.2012.713548

Tondeur, J., Roblin, N. P., van Braak, J., Voogt, J. \& Prestridge, S. (2016). Preparing beginning teachers for technology integration in education: Ready for take-off? Technology, Pedagogy and Education, 26(2), 157-177. https://doi.org/10.1080/1475939X.2016.1193556 
Tondeur, J., Scherer, R., Siddiq, F. \& Baran, E. (2017). A comprehensive investigation of TPACK within pre-service teachers' ICT profiles: Mind the gap! Australasian Journal of Educational Technology, 33(3), 46-60. https://doi.org/10.14742/ajet.3504

Urbani, J. M., Roshandel, S., Michaels, R. \& Truesdell, E. (2017). Developing and modeling 21st-century skills with preservice teachers. Teacher Education Quarterly, 44(4), 27-50.

Voogt, J., Fisser, P., Roblin, N. P., Tondeur, J. \& van Braak, J. (2013). Technological pedagogical content knowledge - A review of the literature. Journal of Computer Assisted Learning, 29(2), 109-121. https://doi.org/10.1111/j.1365-2729.2012.00487.x

Voogt, J., Knezek, G., Christensen, R., \& Lai, K. W. (2018). Developing an understanding of the impact of digital technologies on teaching and learning in an ever-changing landscape. In J. Voogt, G. Knezek, R. Christensen, \& K. W. Lai (Eds.), Second handbook of information technology in primary and secondary education, (pp. 3-12). Cham, Switzerland: Springer. https://doi.org/10.1007/978-3-319-71054-9_113

Wiley, D., Bliss, T. J., \& McEwen, M. (2014). Open educational resources: A review of the literature. In J. M. Spector, M. D. Merrill, J. Elen, \& M. J. Bishop (Eds.), Handbook of research on educational communications and technology (pp. 781-789). New York, NY: Springer. https://doi.org/10.1007/978-1-4614-3185-5_63

Yeung, A. S., Lim, K. M., Tay, E. G., Lam-Chiang, A. C., \& Hui, C. (2012). Relating use of digital technology by pre-service teachers to confidence: A Singapore survey. Australasian Journal of Educational Technology, 28(8), 1317-1332. https://doi.org/10.14742/ajet.774 